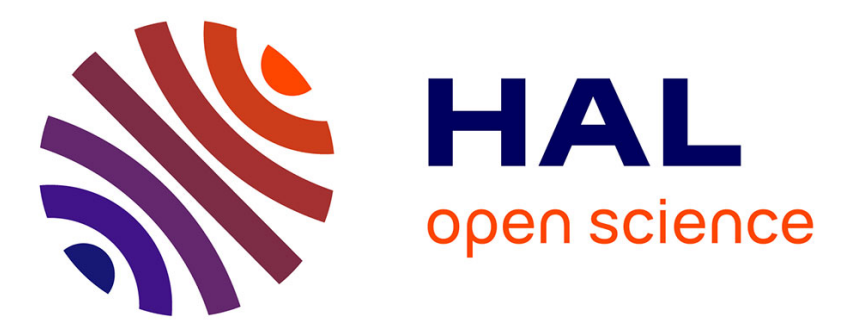

\title{
Taxonomic review of the genus Paranisitra Chopard (Orthoptera: Gryllidae: Eneopterinae: Nisitrini) with description of a new species from Mindanao
}

Jessica B Baroga-Barbecho, Sheryl A Yap, Ming Kai Tan, Tony Robillard

\section{- To cite this version:}

Jessica B Baroga-Barbecho, Sheryl A Yap, Ming Kai Tan, Tony Robillard. Taxonomic review of the genus Paranisitra Chopard (Orthoptera: Gryllidae: Eneopterinae: Nisitrini) with description of a new species from Mindanao. Zootaxa, 2019, 4568 (1), pp.81. 10.11646/zootaxa.4568.1.5 . hal-02626287

\section{HAL Id: hal-02626287 \\ https://hal.science/hal-02626287}

Submitted on 26 May 2020

HAL is a multi-disciplinary open access archive for the deposit and dissemination of scientific research documents, whether they are published or not. The documents may come from teaching and research institutions in France or abroad, or from public or private research centers.
L'archive ouverte pluridisciplinaire HAL, est destinée au dépôt et à la diffusion de documents scientifiques de niveau recherche, publiés ou non, émanant des établissements d'enseignement et de recherche français ou étrangers, des laboratoires publics ou privés. 


\title{
Taxonomic review of the genus Paranisitra Chopard (Orthoptera: Gryllidae: Eneopterinae: Nisitrini) with description of a new species from Mindanao
}

\author{
JESSICA B. BAROGA-BARBECHO ${ }^{1, *}$, SHERYL A. YAP ${ }^{2,3}$, MING KAI TAN $^{4}, \&$ \\ TONY ROBILLARD 5 \\ ${ }^{1}$ Office of the Vice Chancellor for Research and Extension, University of the Philippines Los \\ Baños, College, Laguna, 4031 Philippines. Email: jbbaroga@up.edu.ph \\ ${ }^{2}$ Institute of Weed Science, Entomology and Plant Pathology, University of the Philippines Los \\ Baños, College, Laguna, 4031 Philippines. Email: sayap3@up.edu.ph \\ ${ }^{3}$ Museum of Natural History, University of the Philippines Los Baños, College, Laguna, 4031 \\ Philippines. \\ ${ }^{4}$ Department of Biological Sciences, National University of Singapore, 14 Science Drive 4, \\ Singapore 117543, Republic of Singapore.Email: orthoptera.mingkai@gmail.com \\ ${ }^{5}$ Institut de Systématique, Evolution et Biodiversité (ISYEB), Muséum national d'Histoire natu- \\ relle, CNRS, Sorbonne Université, EPHE, 57 rue Cuvier, CP 50, 75231 Paris Cedex 05, France. \\ E-mail: tony.robillard@mnhn.fr \\ *corresponding author
}

\begin{abstract}
The genus Paranisitra Chopard (Orthoptera: Gryllidae: Eneopterinae: Nisitrini) is reviewed. New records and additional descriptions are provided for $P$. longipes Chopard, P. leytensis Robillard, and P. septentria Baroga, Yap \& Robillard, and a new species is described from Mindanao: Paranisitra flavofacia n. sp. A taxonomic key and updated checklist of the genus Paranisitra in the world are also provided.
\end{abstract}

Key words: checklist, key, new record, new species, Paranisitra, taxonomy 


\section{Introduction}

The Philippines is composed of more than 7,100 islands and it is considered as one of the mega biodiversity hotspots in the world because of its high levels of species richness and variation among adjacent regions (Brown \& Diesmos 2009). Although the fauna of every island in the country is unique, only few taxonomists have been able to study all of them in detail (Tan et al. 2017). Most of the faunistic studies being done were concentrated in Luzon Island, and only limited works have been done in Mindanao Island, particularly on crickets (Tan et al. 2017).

The genus Paranisitra Chopard, 1925 includes distinct species of wingless, long-legged crickets that can be found dwelling on low vegetation during daytime, near or within rainforest. In addition to the complete absence of wings in both sexes, the genus is also characterized by its very short abdomen and cerci, and head shape with narrow fastigium, large prominent eyes and protruding rounded ocelli (Gorochov 2009; Robillard \& Yap 2015; Baroga et al. 2016). Species under this genus are most often yellow brown, with specific black and yellow patterns.

The genus was established by Chopard (1925) for the species $P$. longipes Chopard, 1925 from the Philippines (Luzon Island: Mount Makiling). It remained monotypic until Gorochov (2009) described P. diluta Gorochov, 2009 and P. maculata Gorochov, 2009 from Indonesia (Supiori Island, north of New Guinea Island) and the Philippines (Mindoro Island) respectively. More recently, P. leytensis Robillard, 2015 was described from Leyte Island (Robillard \& Yap 2015), and P. septentria Baroga, Yap \& Robillard, 2016 from Luzon Island (Mt. Pau) (Baroga et al. 2016), both from the Philippines.

In this paper, we describe the new species of Paranisitra flavofacia n. sp. from Mindanao Island and Siargao Island and provide new records and additional descriptions for $P$. longipes Chopard, 1925, P. leytensis Robillard, 2015, and P. septentria Baroga, Yap \& Robillard, 2016. A complete checklist, distribution map, and key to Paranisitra species are also provided. 


\section{Materials and Methods}

\section{Material examined}

Newly collected specimens studied herein come from selected forested areas in the Philippines. These crickets were captured during day and night using sweep nets or by hand using a wide-mouthed plastic vial. Specimens were preserved in $80 \%$ ethyl alcohol or absolute analytic-grade ethanol. Collected specimens were brought to the laboratory for dry mounting and identification. Other materials were loaned from or observed in Bernice P. Bishop Museum (BPBM), Muséum national d'Histoire naturelle (MNHN), Zoological Reference Collection (ZRC) in Lee Kong Chian Natural History Museum, University of the Philippines Los Baños Museum of Natural History (UPLBMNH), Institute of Weed Science, Entomology, and Plant Pathology-Taxonomy Laboratory (IWEP-Taxo. Lab.), and National Museum of the Philippines (NMP). Information in brackets in the lists of materials refer to information not present on specimens' labels.

\section{Observations and morphological analysis}

Direct observations and dissections of the genitalia have been made using a dissecting microscope. General morphology follows terminology by Ragge (1955), DesutterGrandcolas (2003), Robillard \& Desutter-Grandcolas (2004a), and Gorochov (2009). Dissection and preservation of male and female genitalia as well as the measurements of characters follows Robillard \& Yap (2015) and Baroga et al. (2016). Photographs of the habitus, genitalia, and other important morphological characters were taken using AmScope MU1000 digital camera and Canon EOS 50D digital SLR camera with a macro photo lens MP-E 65mm f/2.8 USM (1-5x). Canon Macro Twin Lite MT-24EX and Canon Macro Ring Lite MR-14EX were used for lighting and flash. Image editing was accomplished using Adobe Photoshop CC 2014.

\section{Abbreviations}

Descriptions: General morphology: Tarsomere III-1, III-3: first and third segments of hind leg tarsomere. 
Measurements: FIIIL, length of hind femora; FIIIW, width of hind femora; OL, ovipositor length; PronL, pronotum length; PronW, pronotum width; TIIIL, length of hind tibiae.

\section{Institutions:}

BPBM Bernice P. Bishop Museum, Honolulu, Hawaii, USA;

MNHN Muséum national d'Histoire naturelle, Paris, France;

ZRC Zoological Reference Collection, Lee Kong Chian Natural History

Museum, Singapore;

UPLBMNH University of the Philippines Los Baños Museum of Natural

History, Laguna, Philippines;

IWEP-Taxo. Lab. Institute of Weed Science, Entomology, and Plant PathologyTaxonomy Laboratory, UP Los Baños, Laguna, Philippines;

NMP National Museum of the Philippines, Manila.

ZIN Zoological Institute of Russian Academy of Sciences, Russia

\section{Systematic part}

\section{Key to species of Paranisitra Chopard, 1925}

1. Face with white or yellow transverse band ............................................................... 2

- Face without white or yellow transverse band ................................................................ 4

2. Body spotted; male genitalia with lateral endophallic sclerites and almost not hooked at apex P. maculata Gorochov, 2009

- Body not spotted ..................................................................................................

3. Body coloration usually yellow brown with black and yellow patterns; male genitalia with rounded and wide pseudepiphallic lophi P. longipes Chopard, 1925

- Body coloration lighter than other species; male genitalia with smaller and triangular pseudepiphallic lophi P. leytensis Robillard, 2015

4. Face entirely black; male genitalia with membranous lophi and ectophallic fold have strong leaf-like lateral sclerites P. septentria Baroga, Yap, \& Robillard, 2016 
- Face entirely yellow.

5. Presence of dark longitudinal band on hind femora; male genitalia pseudepiphallic lophi longer than wide, endophallic sclerite with lateral arms curved anteriorly

P. flavofacia n. sp.

- Absence of dark longitudinal band on hind femora; male genitalia with short and rounded pseudepiphallic lophi, wider than long; endophallic sclerite with lateral arms curved posteriorly and distinctly hooked at apex

P. diluta Gorochov, 2009

\section{Family Gryllidae}

\section{Subfamily Eneopterinae Saussure, 1874}

\section{Tribe Nisitrini Robillard, 2004}

\section{Paranisitra Chopard, 1925}

Paranisitra Chopard, 1925: 291.

Type species. Paranisitra longipes Chopard, 1925, by original monotypy

Emended diagnosis from Robillard \& Yap (2015). Size average for the subfamily. Coloration of adults dominantly yellow brown with specific black and yellow patterns variable between species. Head shape with narrow fastigium, antenna very long, large prominent eyes and protruding rounded ocelli. Pronotum not carinated; its lateral angles rounded, posterior edge slightly concave, lateral lobes almost triangular. Wings completely absent in both sexes. Legs long and thin. Fore tibia with two tympana, inner one slit-like, covered by a swollen cuticular expansion; outer tympanum oval, its membrane transversally plicate in dorsal half. Fore tibia with three apical spurs, two inner and one outer. Median tibia with four apical spurs, inner longest. Hind tibia with three inner and three outer apical spurs, median longest on each side; four inner subapical spurs and only three outer subapical spurs (four in other eneopterine genera), inner and outer spurs almost straight, their apex hook-like. Hind tibia serrulated on whole length, dorsal 
face slightly furrowed. Tarsomeres III- 1 with two rows of spines on external edge (one dorsal and one more lateral) in addition to apical spines. Apical claws of legs slightly indented. Abdomen and cerci short. Male genitalia membranous and setose; pseudepiphallic lophi short but well individualized. Female ovipositor apex thin and not denticulate; copulatory papilla conical to diamond-shaped, with a basal sclerotized ring.

\section{Paranisitra longipes Chopard, 1925}

(Fig. 1)

Paranisitra longipes Chopard, 1925: 318 (original description). Gorochov 2009: 436 (redescription); Robillard \& Desutter-Grandcolas 2004: 658 (morphological phylogeny), 2006 (molecular phylogeny), 2008: 67 (classification); Nattier et al. 2011 (molecular phylogeny); Robillard \& Yap 2015: 85; Baroga et al. 2016: 94 (taxonomic key); Vicente et al. 2017: 2203 (biogeography).

Type material. Holotype male. Philippines. [Luzon Island, Laguna], Mt. Makiling, Baker, coll. Karny, 1266 (MNHN-EO-ENSIF1192) [examined]. Allotype female. Philippines. same information as HT (MNHN-EO-ENSIF446) [examined].

Other material examined. Philippines. Luzon [Island]: Laguna: Los Baños, Mt. Makiling: $1 \bigcirc$ (JBB238), 15.ii.2014, coll. A.K. Amarga \& E.C. Rubico (IWEP Taxo Lab02978); 2 ㅇ (JBB019-020), 3今 (JBB021-023), 15-16.ii.2014, coll. N.M. Barbecho (UPLBMNH); 19 (JBB014), 06.i.2014, coll. J.B. Baroga (UPLBMNH); 19 (JBB109), 15.viii.2014, coll. J.B. Baroga (UPLBMNH); Plot 3, 1 ㅇ (JBB144), 20.v.2015, coll. N.M. Barbecho (UPLBMNH); 300 m, 1ð (JBB281), 19.v.1904, coll. S. Rosario (UPLBMNH ORT-01124); 3500 m, 10ิ (JBB283), 3500 ft, 1 ㅇ (JBB285), 26.iv.1958, coll. C.E. Mendoza (UPLBMNH ORT-01126, 01128), 1500 ft, 1 (JBB286), 26.iv.1958, coll. B.D. Morallo (UPLBMNH ORT-01129). Mount Makiling, base, $14^{\circ} 09^{\prime} 12,9^{\prime \prime} \mathrm{N}$ 121 14'05,0"E, 168 m, 2011-2014, T. Robillard, 5ㅇ, 7 万, 9 juveniles (MNHN); Los Banos, Laguna, Mount Makiling, base, Aguila base, to summit \#2, $14^{\circ} 08^{\prime} 15,2^{\prime \prime} \mathrm{N}$ 121ำ1'47,7"E, 2011-2014, 1ð, 4ㅇ, 1 juvenile (MNHN). Makiling Botanic Garden: 1 우 
(JBB244), 02.iv.2016, coll. J.E. Umerez (IWEP Taxo Lab-30231); 1ð (JBB274), 26.xii.1985, coll. E. Oratai (UPLBMNH ORT-01117). UPLB, Pook ni Mariang Makiling, 1 ( JBB178), 18.iii.2014, coll. I.J. Llanto (UPLBMNH). Los Baños: $50 \mathrm{~m}, 1$ ㅇ (JBB287), 12.v.1964, 1ð (JBB282), 13.v.1964, coll. R.R. Reyes (UPLBMNH ORT01130, 01125); $1 ð$ juvenile (JBB288), 28.ii.1976, coll. H. Baguinon (UPLBMNH ORT01131); $1{ }^{\Uparrow}$ (JBB236), 25.i.2014, coll. Saranya S. (IWEP Taxo Lab-02981). Dampalit Falls, 19 (JBB179), 11.i.2014, coll. J.B. Baroga (UPLBMNH). Cavinti: cave, $3{ }^{\Uparrow}$ (JBB194, JBB183, JBB190), 24.v.2014, coll. N.M. Barbecho (UPLBMNH ORT-0081900821); night, 19 (JBB195), 7 (JBB188, JBB184, JBB187, no code, JBB191, JBB185, JBB193), 26.v.2014, coll. N.M. Barbecho (UPLBMNH ORT-00863-00867, 0087200874); 10 (JBB186), 10 juvenile (JBB199), 27.v.2014, coll. N.M. Barbecho (UPLBMNH ORT-00890-00891). Majayjay, 1ð̂ juvenile (JBB235), 01.iii.2009, coll. N.R. Barnacha (IWEP Taxo Lab-02982). [Quezon Province]: [Real], NBG [National Botanic Garden]: 10.ii.1985 1ð (JBB278), coll. C.L. Dayanon (UPLBMNH ORT01121), 10 (JBB234), 15.ii.1985 (IWEP Taxo Lab-02990); 20 (JBB276-277), 18.ii.1984, coll. N. Hasan (UPLBMNH ORT-01119-01120); 2000 ft., $1 \overbrace{}^{\Uparrow}$ (JBB279), 2.xii.1976, C.R. Baltazar (UPLBMNH ORT-01122); grasses, $1 \overbrace{}^{\Uparrow}$ (JBB280), 22.iii.1976, P.L. Bugayong (UPLBMNH ORT-01123). Polillo Island: 1ðð (JBB232), 17.iii.2009, coll. R.E. Bayot (IWEP Taxo Lab-02988); 1 ( (JBB241), 08.iv.2016, coll. P.C.T. Salazar (IWEP Taxo Lab-30234), Pinaglubayan: 2へ (JBB031-032), 4-6.vi.2014, coll. J.B. Baroga, F. Signabon \& S.A. Yap (UPLBMNH). Real, UPLB Land Grant, 1 ㅇ (JBB364), 10 (JBB365), 20-24.i.2016, coll. K.O. Abenis (UPLBMNH). [Camarines Sur]: Mt. Iriga, 500-600 m: 1ðิ (JBB367), 10.iv.1962, coll. H.M. Torrevillas (BPBM); 10 (JBB369), 19.iv.1962, coll. H.M. Torrevillas (BPBM); 1ठ (JBB370), 23.iv.1962, coll. H.M. Torrevillas (BPBM). Mt. Isarog: $20 \mathrm{~km}$ of Naga, 500-600 m, light trap, 1§ (JBB371), 6.iv.1963, coll. H.M. Torrevillas, (BPBM); 500-600 m, 1ð^ (JBB373), 11.iv.1963, coll. H.M. Torrevillas (BPBM); 750-900 m, 2へ (JBB377-378), 4-7.iv.1963, coll. H.M. Torrevillas (BPBM); 750-850 m, 10 (JBB379), 8-12.v.1963, coll. H.M. Torrevillas (BPBM); 750-850 m, 1ð (JBB380), 15-17.v.1963, coll. H.M. Torrevillas (BPBM); 800 m, light trap, 10 (JBB383), 28.iv.1965, coll. H.M. Torrevillas (BPBM). [Albay]: Mt. Malinao: $1 \hat{\jmath}$ (JBB025), 1 ㅇ (JBB175), 1-3.iii.2014, coll. J.B. Baroga (UPLBMNH); $1 \hat{}$ 
(JBB007), 24-25.x.2013, coll. S.A. Yap (UPLBMNH); 1ð (JBB233), 24.x.2013, coll. A.K. Amarga \& J.M. Briz (IWEP Taxo Lab-02983); no data, 1ð (JBB284) (UPLBMNH ORT-01127).

Type locality. Philippines, Luzon Island, Laguna, Mount Makiling.

Distribution. Philippines, Luzon Island: Laguna Province: Mt. Makiling, Makiling Botanic Garden, Dampalit Falls (new record), Majayjay (new record), Cavinti (new record). Quezon Province: Real (new record), Polillo Island (new record). Camarines Sur Province: Mt. Iriga [formerly known as Mt. Asog] (new record); Mt. Isarog (new record); Albay Province: Mt. Malinao (new record).

Diagnosis. General shape slender, body not spotted (unlike in P. maculata); coloration usually yellow brown with more or less black and yellow patterns. Face with a wide yellow transverse band as in P. leytensis and P. maculata; differing from P. leytensis by larger size and male genitalia with pseudepiphallic lophi wider and rounded, and from $P$. maculata by less spotted body coloration.

Paranisitra maculata Gorochov, 2009

(Fig. 1)

Paranisitra maculata Gorochov, 2009: 436; Baroga et al. 2016: 94 (taxonomic key); Vicente et al. 2017: 2203 (biogeography).

Type material. Holotype male. Philippines. Mindoro Island, northern coast, environs of Puerto Galera town, 11-13.iv.2004, coll. A. Gorochov (ZIN) [examined]. Paratypes. Philippines. Mindoro I., env. de Puerto Galera (N. coast), 10", 11.iii..2004-13.iii.2004, Gorochov A. (MNHN-EO-ENSIF3682), 19, , molecular sample N8Pma (MNHN-EOENSIF3683) [examined]. 8§̂, 3ㅇ, same information (ZIN) [examined] 
Other material examined. [Philippines]. Mindora [Mindoro], coll. Br. v. W., 19.024, $1 \uparrow,($ MNHN-ENSIF646); Philippinen [Philippines], Mindoro, $19,($ MNHN-ENSIF647).

Type locality. Philippines. Luzon, Mindoro Island, northern coast, environs of Puerto Galera.

Distribution. Philippines: Mindoro Island.

Diagnosis. Species similar to P. longipes for having the yellow transverse band in the face, differing by larger size and body heavily spotted; male genitalia with lateral endophallic sclerites rather wide, and almost not hooked at apex.

Paranisitra diluta Gorochov, 2009

(Fig. 1)

Paranisitra diluta Gorochov, 2009: 438. Vicente et al. 2017: 2203 (biogeography).

Type material. Holotype male. Indonesia. Supiori Island (not far from northern edge of western New Guinea), southern coast, environs of Korido village, 10-11 November 2004, coll. A. Gorochov [not examined]. Paratypes. Indonesia. Southern coast of Supiori I. (not far from N. coast of W. New Guinea), on hills near vill. Korido, primary forest, 10.xi.2004-11.xi.2004, Gorochov A., 10̃, molecular sample N16Pdi2 (MNHN ENSIF3681) [examined]. Indonesia. Northern coast of Biak I. (not far from N. coast of W. New Guinea), on hills near vill. Corem [Korim], primary forest, 19, 14.xi.200415.xi.2004, Gorochov, A., molecular sample N9Pdi (MNHN ENSIF3680) [examined]. $5 \hat{\jmath}, 5$ ㅇ, same information (ZIN) [examined].

Type locality. Indonesia. Papua Province, Supiori Island, environs of Korido village. 
Distribution. Indonesia: Supiori Island and Biak Island.

Diagnosis. Size average, body less spotted than $P$. longipes and $P$. maculata and without dark longitudinal band on hind femora. Face almost completely yellow. Absence of large dark spots and bands on dorsal disc and lateral lobes of pronotum. Male genitalia with short and rounded pseudepiphallic lophi; lateral arms of endophallic sclerite narrower than in $P$. maculata. Female ovipositor shorter than in P. longipes.

\section{Paranisitra leytensis Robillard, 2015}

(Fig. 1)

Paranisitra leytensis Robillard \& Yap, 2015: 85; Baroga et al. 2016: 94 (taxonomic key).

Type material. Holotype male. Philippines. [Visayas]: Leyte [Island], Burauen, Barangay Villa Corazon, zone herbacée [herbaceous area] (GPS Bar1), 10 $57^{\circ} 50.5^{\prime \prime} \mathrm{N}$ 1244ㅇ' 35.3"E, 282 m (TR14), iii.2013, coll. T. Robillard (UPLBMNH). Allotype female. Philippines. [Visayas]: Leyte [Island]: Buo, zone secondaire près de la route [secondary area near road], (TR34), iii.2013, coll. T. Robillard (UPLBMNH). Paratypes (1 male, 5 females). Philippines. same information as HT and AT (MNHN-EO-ENSIF3162-3166). [examined]

Other material examined. Philippines. [Mindanao]: [Surigao del Norte]: Siargao Island, Del Carmen, Brgy. Esperanza, 10ิ (JBB139), 01-05.x.2016, coll. S.A. Yap (UPLBMNH), right middle leg for molecular analysis (N40); Del Carmen, Brgy. Katipunan, 2 , , 07.iv.2018, rainy, coll. J.B. Baroga-Barbecho, S.A. Yap, M.K. Tan, \& H. Yeo (UPLBMNH, ZRC); 2 ㅇ (Siargao18_44, 84), 14-17.x.2018, coll. M.K.Tan, J.B. Baroga-Barbecho \& S.A. Yap (ZRC). [Mindanao Island: Agusan del Sur]: Casawangan Lake, 10 (JBB363), 22.vii.2015, coll. N.M. Barbecho (NMP 13579), left middle leg for molecular analysis (N39).

Type locality. Philippines. Visayas, Leyte Island, Burauen, Barangay Villa Corazon, 
$10^{\circ} 57^{\prime} 50.5^{\prime \prime} \mathrm{N} 124^{\circ} 46^{\prime} 35.3^{\prime \prime} \mathrm{E}, 282 \mathrm{~m}$.

Distribution. Philippines. Visayas: Leyte Island; Mindanao: Siargao Island (new record); Mindanao Island: Agusan del Sur (new record).

Diagnosis. Species close to $P$. longipes in terms of face coloration with a wide yellow band; differing by its smaller size and male genitalia with smaller and triangular pseudepiphallic lophi, shorter endophallic sclerite, and narrower endophallic apodemes.

Remarks. The male specimens from Siargao Island and Mindanao Island (Agusan del Sur) were identified as $P$. leytensis based on the features of the body, face, size and male genitalia. They slightly differ from the specimens from Leyte by the following characters: in Siargao specimens, male genitalia wider than long, short and less setaceous lophi, and short rami; in Agusan specimen, thin and long male genitalia, ectophallic fold longer and narrowing basally. Male specimen from Mindanao Island is the smallest among examined specimens of the species.

\section{Paranisitra septentria Baroga, Yap \& Robillard, 2016}

(Figs 1, 2)

Paranisitra septentria Baroga, Yap \& Robillard, 2016: 100.

Type material. Holotype male. Philippines. [Luzon Island]: [Ilocos Norte]: Adams, Mt. Pau, secondary forest, N18.45, E120.866, day, rainy, col. J. B. Baroga, S. A. Yap, V. Yngente \& W. Bulalacao (JBB011), 30.xi-2.xii.2013, (UPLBMNH ORT-01097). [examined]

Additional material examined. Philippines. [Luzon Island]: [Ifugao]: Mayoyao, Mt.[Mountain] Province, 1ð (JBB384), 10.viii.1966, coll. H.M. Torrevillas (BPBM). 
Bunhian, Jacmal, 24 km E Mayoyao, 800-1000 m, 1 (JBB385), 4-6.v.1967, coll. H.M. Torrevillas (BPBM).

Type locality. Philippines, Luzon Island, Ilocos Norte, Adams, Mt. Pau.

Distribution. Philippines. Luzon Island: Ilocos Norte: Mt. Pau; Mountain Province, Ifugao (new records).

Diagnosis. Species differing from other species of the genus by face and mouthparts entirely dark brown. Male genitalia with membranous lophi and ectophallic fold with strong leaf-like lateral sclerites, while rounded in P. leytensis. Female copulatory papilla elongate and with lateral striations.

Addition to the description. Female (Fig. 2a-b). In addition to the general morphology and characters of male presented in Baroga et al. (2016). Size larger than male. Coloration brown to dark brown. Vertex black, with brown patterns. Fastigium brown with three long apical setae; ocelli brown, protruding and outlined with black lining. Scapes yellow, antennae brown with white rings. Face entirely black; frons with two yellow spots. Maxillary palpi white. Ovipositor slightly shorter than hind femur. Copulatory papilla (Fig. 2c-d) elongate, longer than P. longipes and P. leytensis, with a narrowed basal sclerotized ring; its lateral margins with some striations; apex bisunated.

Measurements in mm. see Table 1.

\section{Paranisitra flavofacia n. sp.}

(Figs 1, 3-7)

Type material. Holotype male. Philippines. [Mindanao Island]: [Zamboanga del Sur]: $32 \mathrm{~km} \mathrm{NW}$ of Milbuk, rain forest, light trap, $900 \mathrm{~m}$, 6.viii.1958 (JBB386), coll. H.E. Milliron (BPBM). Allotype female. Philippines. [Mindanao Island]: [Misamis 
Occidental]: Don Victoriano, Lake Duminagat, 1395 asl, Agro-ecosystem, grass dominated, 17.xi.2003 (JBB243), coll. M.C. Espallardo, left fore leg for molecular analysis (N38) (IWEP-Taxo. Lab-02989). Paratypes. Philippines. [Mindanao Island]: [Misamis Oriental]: Mt. Kibungol, 20 km SE of Gingoog, 700-800 m, 1 q (JBB390), 2 (JBB392-JBB393), 9-18.iv.1960, coll. W. Torrevillas (BPBM). Minalwang, 1050 m, 1 (JBB394), 24.iii.4.iv.1961, coll. W Torrevillas (BPBM). Minubatan, 1050-1200 m, 1 q (JBB395), 5-9.iv.1961, coll. H Torrevillas (BPBM). Mt. Empagatao, 1050-1200 m, 3 q (JBB396-JBB398), 19-30.iv.1961, coll. H Torrevillas (BPBM). [Zamboanga del Sur]: 24 km NW of Milbuk nr. Lebak, 450-900 m, 1 ( (JBB387), 6-7.viii.1958, coll. H. E. Milliron (BPBM). [Agusan]: San Francisco 10 km, SE, 1 (JBB388), 15.xi.1959, coll. C.M. Yoshimoto (BPBM). Dos Arcos, 19 (JBB389) 19-23.xi.1959, coll. C. M. Yoshimoto (BPBM). Mindanao, 1q, coll. Br.v.W. [Brunner von Wattenwyl], 21.181, identified Paranisitra longipes by T. Robillard (MNHN-EO-ENSIF648).

Other material examined. Philippines. [Mindanao]: [Surigao del Norte]: Siargao Island, Del Carmen: Brgy. Esperanza, 01-05.x.2016, 2 q (JBB140,142), coll. S.A. Yap; left middle leg of JBB140 for molecular analysis (N41) (UPLBMNH), 1 (JBB141) (MNHN-EO-ENSIF1548), $2 \hat{\sigma} \quad 6 \% \quad$ (UPLBMNH). Brgy. Katipunan N9.87637 E126.00936, 34.5 \pm 4.7 m.a.s.1, 07.iv.2018, rainy, coll. J.B. Baroga-Barbecho, S.A. Yap, M.K. Tan, \& H. Yeo, $1 \hat{\jmath}$ (UPLBMNH), $1 \widehat{o}$ (Siargao18_04), $1 q$ (Siargao18_21) (ZRC), 1q, molecular sample N50 (MNHN-EO-ENSIF4123). Brgy. Sayak N9.86026 E126.03296, $51.1 \pm 6.4$ m.a.s.1, 08.iv.2018, rainy, coll. J.B. Baroga-Barbecho, S.A. Yap,

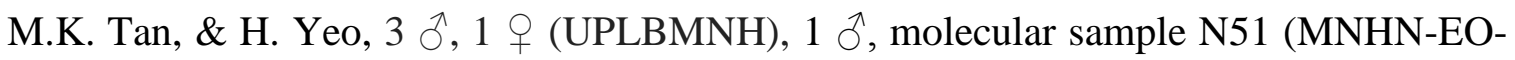
ENSIF4121), 1 은 (MNHN), 1 (Siargao18_29) (ZRC). [Mindanao Island]: [Misamis Oriental]: Mt. Kibungol, 20 km SE of Gingoog, 700-800 m, 1 juvenile (JBB391), 918.iv.1960, coll. W. Torrevillas (BPBM).

Type locality. Philippines, Mindanao Island: Zamboanga del Sur.

Distribution. Philippines, Mindanao: Mindanao Island, Zamboanga Peninsula,Siargao Island. 
Etymology. The name of the species comes from the combination of the Latin words "flavo" meaning yellow and "faciem" meaning face.

Diagnosis. Species of average size, characterized as in $P$. diluta by its entirely yellow face, without transverse band; differing from $P$. diluta by male genitalia with pseudepiphallic lophi longer than wide and forming a triangle (shorter and rounded in $P$. diluta), and by lateral arms of endophallic sclerite curved anteriorly.

Description. Size average for the genus (Fig. 3). Coloration yellow to golden brown. Head vertex (Fig. 4a) black, with some yellow to brown patterns, covered with whitish setae. Fastigium black, area posterior to ocelli brown; ocelli rounded, protruding and outlined with black. Scapes and antennae yellow to dark brown with whitish rings widely spaced out. Entire face and mouthparts yellow, without transverse band (Fig. 4b); maxillary palpi whitish to yellowsh. Frons with a dark brown marking. Head lateral side yellowish (Fig. 4c), area below eyes brown. Dorsal disc of pronotum brown, with dark brown markings. Lateral lobes of pronotum dark brown, covered with short white setae; ventral margin golden brown. Legs brown to dark brown. Fore- and median femora orange brown, covered with dark setae. Hind femora yellowish basally, darker apically, with white markings and longitudinal bands on external face; knees dark brown. Tibiae dark brown, lighter basally. Tarsomeres brown apically, lighter basally. Tarsomeres III-1 with 3-10 spines on dorso-external edge. Abdomen orange brown to golden brown, mottled with black markings. Cerci homogenously dark brown, without markings and rings, covered with hairs.

Male. Male genitalia (Fig. 5a-c). Pseudepiphallus wide and slightly conical, its anterior margin slightly indented. Lophi membranous, thin and elongated, forming short triangles slightly indented laterally. Rami long, curved and converging apically. Pseudepiphallic parameres narrow, fused to pseudepiphallus dorsally, with strong rounded lateral sclerites, narrowing apically. Ectophallic apodemes long, reaching half of size of rami, parallel. Endophallic sclerite sclerotized, its posterior apex with long divergent lateral 
arms and with a short triangular median expansion. Endophallic apodeme including wide and thick lateral lamellas, and a long strongly sclerotized dorsal crest.

Female. Habitus similar to males (Fig. 3), but body coloration (including fastigium vertex, legs, and abdomen) tends to be less dark. $3^{\text {rd }}$ abdominal tergite with dark median patterns. Ovipositor shorter than hind femora, apex black, fainter apically, its apex smooth and pointed. Copulatory papilla (Fig. 5d-e) wider than long laterally and longer than wide dorsally, with a basal sclerotized ring; apex slightly bent.

Juveniles. Coloration pattern similar to adults, except face, back with a vertical yellow stripe.

Measurements in mm. see Table 2.

Remarks. We observed minor difference in the features of the face of materials from Siargao. Compared with the type material, Siargao specimens are 1.2 times smaller and exhibit small differences in male genitalia, which are not sufficient to support description of a separate species. More information from other localities in Mindanao Island and near Siargao Island and molecular data will be necessary to test whether there are several closely related species. In addition, in both Mindanao and Siargao islands specimens, a few females are strikingly darker than the rest of the series, showing a face almost entirely black and wide black longitudinal band on FIII. However, despite this difference of melanization, the light/dark patterns are more or less similar.

Habitat and life history traits. Materials from Siargao were collected in an agroforestry area dominated with coconut trees. Courting and mating were observed on top of vegetation both in field and secondary herbaceous areas during night time (Fig. 7).

\section{Discussion}

The updated checklist of Paranisitra species is presented in Table 3. Today, a total of six 
species of Paranisitra are recorded, including P. flavofacia $\mathbf{n}$. sp. described here. Five of these species are from the Philippines: three from island group of Luzon, one from Visayas, and one from Mindanao, and only one is distributed in the north of New Guinea Island (Indonesia: Supiori Island).

Most species of the genus have been discovered recently from islands where the orthopteran fauna has been little studied. In such regions, even common and abundant species of crickets often remain undescribed (Robillard 2011; Vicente et al. 2015; Tan et al. 2019). For example, $P$. flavofacia n. sp. seems relatively well distributed in the large island of Mindanao. It is thus very likely that other species of Paranisitra will be discovered during future field surveys in undisturbed areas in Luzon and Mindanao, or in islands from where no material of the genus exists yet in the collections, such as in Palawan, Batanes, large islands of the Visayas (i.e., Negros, Romblon, and Samar) and other parts of Mindanao (i.e., Davao, Sulu, and Basilan).

The taxonomy of Paranisitra still needs clarification. Owing to the fact that the genus is apterous and does not produce songs, we cannot infer species boundaries using wing venation and acoustics. With some species having overlapping distributions, there is a need to examine intraspecific variations more closely to ascertain whether some of the color patterns are indeed diagnostic of the species or merely geographical differences. For example, we observed how nymphs can exhibit variable colorations different from the adults (Fig. 8). Moreover, we should also account for the possibility of introgression among sympatric species to have a better understanding of Paranisistra.

A recent study of molecular phylogeny and historical biogeography about the subfamily Eneopterinae included three species of Paranisistra (Vicente et al. 2017). The results suggested that Paranisitra could have originated in South-east Asia from a divergence with its sister genus Nisitrus ca. $55 \mathrm{Ma}$; then it may have diversified after 12.5 Myrs in the Philippines, before colonizing more recently the north-west of New Guinea (ca. 8.5 Ma). 
Interestingly, several field expeditions in Palawan Island failed collecting any specimen of Paranisistra (A. Gorochov, pers. obs. \& TR, SAY, JBB-B, pers. obs). Although it cannot be considered as a proof of absence, this lack of record despite active search suggests that the genus is not distributed in Palawan. This could be related to the geological history of the region where a landbridge may have existed between the Borneo and Palawan during the late middle Pleistocene (Heaney 1986, Hall 2002). This is particularly relevant to understand the biogeographic history of the tribe Nisitrini, since Palawan is located between the areas of distributions of Paranisitra (mostly in Philippines) and Nisitrus (Borneo, Sumatra, and the Malay Peninsula). At the estimated time of divergence between Paranisitra and Nisitrus ca. $55 \mathrm{Ma}$, the region was drastically different from today (Hall 2002). In particular, Palawan was still related to the Sunda Shelf. It is only recently that this island moved in its current distribution, while the Nisitrini were already diversified. Phylogenetic and biogeographic studies involving a more complete sampling of the Nisitrini will be necessary to analyze more precisely the detailed routes of colonization by this clade in this region of Southeast Asia.

Apart from these biogeographical questions, Paranisitra is relevant to address questions related to the evolution of communication systems in crickets. This genus became mute as a consequence of the complete loss of its wings (Robillard \& Desutter-Grandcolas, 2004). The causes and circumstances of this loss of acoustic communication represent a fascinating topic for future research. It could involve comparisons between Nisitrus and Paranisitra, to assess if they share other modalities of communication (i.e., visual, vibrational) and what aspects of their ecology and behavior could explain the loss of the wings and acoustic communication in Paranisitra.

\section{Acknowledgements}

We are grateful to the Department of Science and Technology-Accelerated Science and Technology Human Resource Development Program (DOST-ASTHRDP) for J.B. Baroga-Barbecho's MS scholarship and to UP-Continuous Operational and Outcomes-based Partnership for Excellence in Research and Academic Training Enhancement (COOP- 
ERATE) Program for the travel grant, which allow us to further examine the specimens at MNHN, Paris France. We also thank the MODECERA project, funded by the DOSTPhilippine Council for Agriculture, Aquatic and Natural Resources Research and Development (PCAARRD) for allowing us to study the collected specimens from Siargao, Mr. Roel Ruzol, the SSCT-Del Carmen Campus especially Ms. Deny Comon, Mr. Jonathan Litang, Mr. Carlos Donoso, and their students for accommodating and accompanying us during fieldworks in Siargao Island. To the Lady Yuen Peng McNeice Graduate Fellowship and Orthoptera Species File Grant 2018 for the research grants that allow M.K. Tan to conduct fieldwork in the Philippines. To Mr. Normandy M. Barbecho of the National Museum of the Philippines for collecting the specimens in Agusan, and for the use of museum equipment and facilities, Ms. Huiqing Yeo for assistance in the collection in Siargao, and Simon Poulain (MNHN, France) for taking photos of the specimens. 


\section{References}

Baroga, J.B., Yap, S.A. \& Robillard, T. (2016) Two new species of Eneopterinae crickets (Orthoptera: Gryllidae) from Luzon, Philippines. Zootaxa, 4139 (1), 93-105. http://dx.doi.org/10.11646/zootaxa.4139.1.5

Brown, R.M. \& Diesmos, A.C. (2009) Philippines, biology. Encyclopedia of Islands. University of California Press, Berkeley, 723-732.

Chopard, L. (1925) Descriptions de Gryllides nouveaux. Annales de Société entomologique de France, 94, 291-332.

Desutter-Grandcolas, L. (2003) Phylogeny and the evolution of acoustic communication in extant Ensifera (Insecta, Orthoptera). Zoologica Scripta, 32 (6), 525-561. http://dx.doi.org/10.1046/j.1463-6409.2003.00142.x

Gorochov, A.V. (2009) A review of the genus Paranisitra Chopard (Orthoptera: Gryllidae: Eneopterinae). Zoological Institute of the Russian Academy of Sciences, 313 (4), 435-439.

Hall, R. (2002) Cenozoic geological and plate tectonic evolution of SE Asia and the SW Pacific: computer-based reconstructions, model and animations. Journal of Asian Earth Science, 20, 353-431.

Heaney, L.R. (1986) Biogeography of mammals in SE Asia: estimates of rates of colonization, extinction and speciation. Biological Journal of the Linnean Society, 28 (12), 127-165.

Ragge, D.R. (1955) The wing venation of the Orthoptera Saltatoria. British Museum (Natural History), Londres, vi +159 pp. 
Robillard, T. (2011) Centuriarus, a new genus of Eneopterinae crickets from Papua (Insecta, Orthoptera, Grylloidea). Zoosystema, 33: 49-60.

Robillard, T. \& Desutter-Grandcolas, L. (2004) Phylogeny and the modalities of acoustic diversification in extant Eneopterinae (Insecta, Orthoptera, Grylloidea, Eneopteridae). Cladistics 20 (3), 271-293.

http://dx.doi.org/10.1111/j.1096-0031.2004.00025

Robillard, T. \& Desutter-Grandcolas, L. (2006) Phylogeny of the cricket subfamily Eneopterinae (Orthoptera, Grylloidea, Eneopteridae) based on four molecular loci and morphology. Molecular Phylogenetics and Evolution, 40 (3), 643-661.

http://dx.doi.org/10.1016/j.ympev.2005.10.019

Robillard, T. \& Desutter-Grandcolas, L. (2008) Clarification of the taxonomy of extant crickets of the subfamily Eneopterinae (Orthoptera: Grylloidea; Gryllidae). Zootaxa, 1789 (1), 66-68.

http://dx.doi.org/10.5281/zenodo.182523

Robillard, T., Yap, S.A. \& Yngente, M.V. (2013) Systematics of cryptic species of Lebinthus crickets in Mount Makiling (Grylloidea, Eneopterinae). Zootaxa, 3693 (1), 4963.

http://dx.doi.org/10.11646/zootaxa.3693.1.3

Robillard, T. \& Yap, S.A. (2015) The Eneopterinae crickets from Leyte Island (Philippines) with description of two new species [Insecta: Orthoptera: Grylloidea: Gryllidae]. The Raffles Bulletin of Zoology, 63, 69-90.

Tan, M.K., Choi, J. \& Shankar, N. (2017) Trends in new species discovery of Orthoptera (Insecta) from Southeast Asia. Zootaxa, 4238 (1), 127-134.

http://dx.doi.org/10.11646/zootaxa.4238.1.10 
Tan, M.K., Gorochov, A.V., Baroga-Barbecho, J.B. \& Yap, S.A. (2019) A new species of Landrevinae (Orthoptera) from the Philippines, with notes on Endodrelanva and Endolandrevus. Zootaxa, in press.

Vicente, N.M., Olivero, P., Lafond, A., Dong, J. \& Robillard, T. (2015) Gnominthus gen. nov., a new genus of crickets endemic to Papua New Guinea with novel acoustic and behavioral diversity (Insecta, Orthoptera, Gryllidae, Eneopterinae). Zoologischer Anzeiger, 258: 82-91.

Vicente N., Kergoat G.J., Dong J., Yotoko K., Legendre F., Nattier R. \& Robillard T. (2017) In and out of the Neotropics: historical biogeography of Eneopterinae crickets. Journal of Biogeography, 44: 2199-2210.

http://dx.doi.org/10.1111/jbi.13026 


\section{Tables:}

Table 1. Measurements of female Paranisitra septentria. Abbreviations, see materials and methods.

Table 2. Measurements of Paranisitra flavofacia $\mathbf{n}$. sp. Abbreviations, see materials and methods.

Table 3. Checklist of Paranisitra species.

\section{Figures:}

Figure 1. Distribution of Paranisitra species.

Figure 2. Paranisitra septentria Baroga, Yap \& Robillard, 2016. Female in dorsal (A) and lateral (B)views. Female copulatory papilla in ventral (C) and lateral (D) views. Scale bars: A-B, $1 \mathrm{~cm}$; C-D, $0.5 \mathrm{~mm}$.

Figure 3. Paranisitra flavofacia n. sp. Male holotype in dorsal (A) and lateral (B) views; fFemale allotype in dorsal (C) and lateral (D) views. h. Scale bar: $1 \mathrm{~cm}$.

Figure 4. Paranisitra flavofacia n. sp. head in dorsal (A), facial (B) and lateral (C) views. Scale bar: $1 \mathrm{~mm}$.

Figure 5. Paranisitra flavofacia n. sp. Male genitalia in dorsal (A), ventral (B), and lateral (C) views. Female female copulatory papilla in ventral (D) and lateral (E) views. Scale bars: A-C, $1 \mathrm{~mm}$; D-E, $0.5 \mathrm{~mm}$. 
Figure 6. Paranisitra flavofacia $\mathbf{n}$. sp. Male (A) and female (B) in natural habitat at night on vegetation along the trail in Del Carmen, Siargao. Photo by M-K Tan.

Figure 7. Paranisitra flavofacia n. sp. Male and female mating during night on vegetation along the trail in Del Carmen, Siargao. Photo by M-K Tan.

Figure 8. A Paranisitra found in Siargao with unique colour patterns different from that of the adult Paranisitra flavofacia n. sp. and Paranisitra leytensis Robillard, 2015. As the specimen was not collected and we could not have a view of the face, the species could not be identified. 
Table 1. Measurement of female Paranisitra septentria. Abbreviations, see materials and methods.

\begin{tabular}{|c|c|c|c|c|c|c|c|c|}
\hline & PronL & PronW & FWL & FWW & HWT & FIIIL & FIIIW & TIIIL \\
\hline $\begin{array}{c}\text { Female } \\
(n=1)\end{array}$ & 19 & 42 & - & - & - & 128 & 27 & 129 \\
\hline (mean) & 19 & 42 & - & - & - & 128 & 27 & 129 \\
\hline & \multicolumn{4}{|c|}{ TIIIs } & \multicolumn{2}{|c|}{ TaIIIs } & ST & \\
\hline & Ias & Ibs & Oas & Obs & Int & Ext & $(n=)$ & OL \\
\hline $\begin{array}{c}\text { Female } \\
(n=1)\end{array}$ & 14 & 11 & 19 & 9 & 1 & 6 & - & 113 \\
\hline (mean) & 14 & 11 & 19 & 9 & 1 & 6 & - & 113 \\
\hline
\end{tabular}

Table 2. Measurements of Paranisitra flavofacia $\mathbf{n}$. sp. Abbreviations, see materials and methods.

\begin{tabular}{ccccccccc}
\hline & PronL & PronW & FWL & FWW & HWT & FIIIL & FIIIW & TIIIL \\
\hline $\begin{array}{c}\text { Male } \\
\text { holotype }\end{array}$ & 21 & 39 & - & - & - & 148 & 30 & 149 \\
$\begin{array}{c}\text { Female } \\
\text { allotype }\end{array}$ & 22 & 31 & - & - & - & 149 & 30 & 145 \\
$\begin{array}{c}\text { Females } \\
\text { (n=6) } \\
\text { (mean) }\end{array}$ & $19-28$ & $31-49$ & - & - & - & $133-$ & $30-39$ & $\begin{array}{c}145- \\
171\end{array}$ \\
\hline & 21 & 40 & - & - & - & 157 & 34 & 162 \\
\hline $\begin{array}{c}\text { Male } \\
\text { holotype }\end{array}$ & 18 & 10 & 27 & 10 & 0 & 0 & - & - \\
$\begin{array}{c}\text { Female } \\
\text { allotype }\end{array}$ & 15 & 10 & 24 & 9 & 1 & 7 & - & 126 \\
$\begin{array}{c}\text { Females } \\
\text { (n=6) }\end{array}$ & $11-16$ & $7-14$ & $22-28$ & $7-11$ & $0-1$ & $5-10$ & - & $98-139$ \\
(mean) & 13 & 10 & 25 & 9 & 1 & 6 & - & 124 \\
\hline
\end{tabular}


Table 3. Checklist of Paranisitra species.

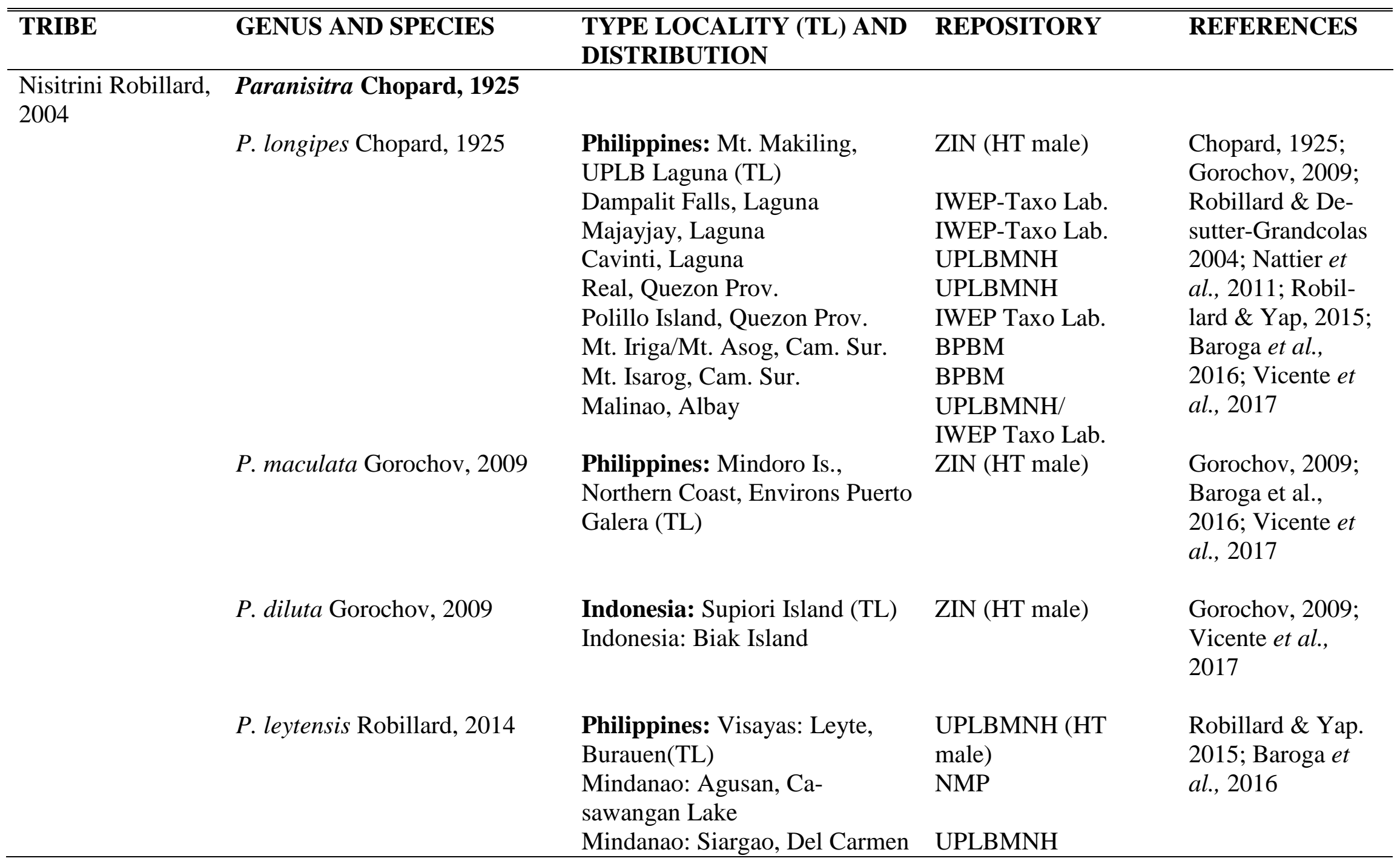


Table 3. continued...

\begin{tabular}{|c|c|c|c|c|}
\hline TRIBE & GENUS AND SPECIES & $\begin{array}{l}\text { TYPE LOCALITY (TL) AND } \\
\text { DISTRIBUTION }\end{array}$ & REPOSITORY & REFERENCES \\
\hline & $\begin{array}{l}\text { P. septentria Baroga, Yap \& Robil- } \\
\text { lard, } 2016\end{array}$ & $\begin{array}{l}\text { Philippines : Mt. Pau, Adams, } \\
\text { Ilocos Norte (TL) } \\
\text { Mountain Province, Ifugao }\end{array}$ & $\begin{array}{l}\text { UPLBMNH (HT } \\
\text { male) } \\
\text { BPBM }\end{array}$ & $\begin{array}{l}\text { Baroga et al., } \\
2016\end{array}$ \\
\hline & P. flavofacia $\mathbf{n}$. sp. & $\begin{array}{l}\text { Philippines: Mindanao: Zamba- } \\
\text { onga del Sur (TL) } \\
\text { Mt. Kibungol, Misamis Or. } \\
\text { Mt. Empagatao, Misamis Or. } \\
\text { Minubatan, Misamis Or. } \\
\text { Minalwang, Misamis Or. } \\
\text { Lake Duminagat, Misamis Occ. } \\
\text { Agusan, Dos Arcos } \\
\text { Agusan, San Francisco } \\
\text { Del Carmen, Siargao }\end{array}$ & $\begin{array}{l}\text { BPBM (HT male) } \\
\text { BPBM } \\
\text { BPBM } \\
\text { BPBM } \\
\text { BPBM } \\
\text { IWEP Taxo Lab. } \\
\text { BPBM } \\
\text { BPBM } \\
\text { UPLBMNH/ZRC/ } \\
\text { MNH }\end{array}$ & \\
\hline
\end{tabular}




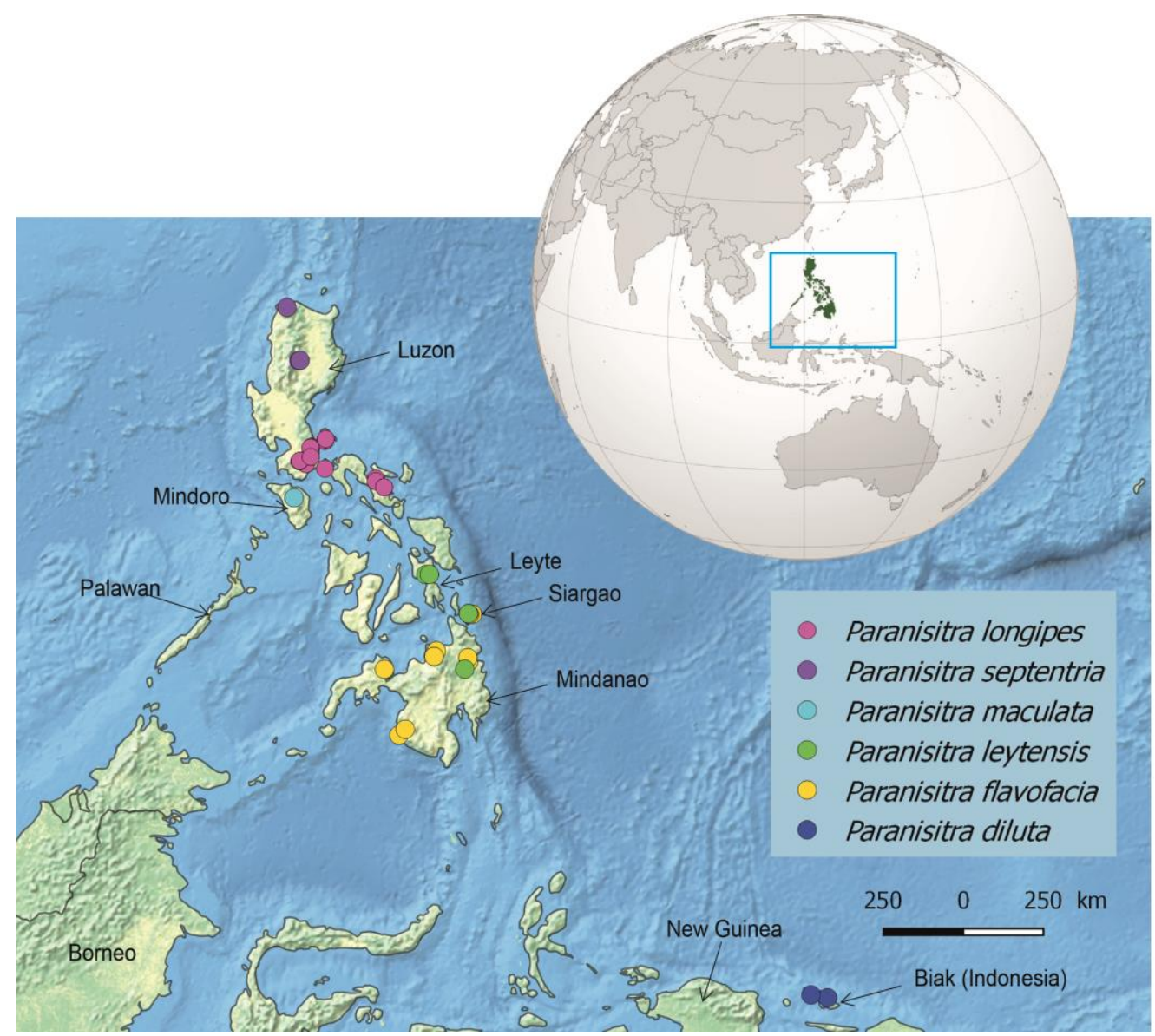

Fig.1. 


$$
11
$$


Fig.3

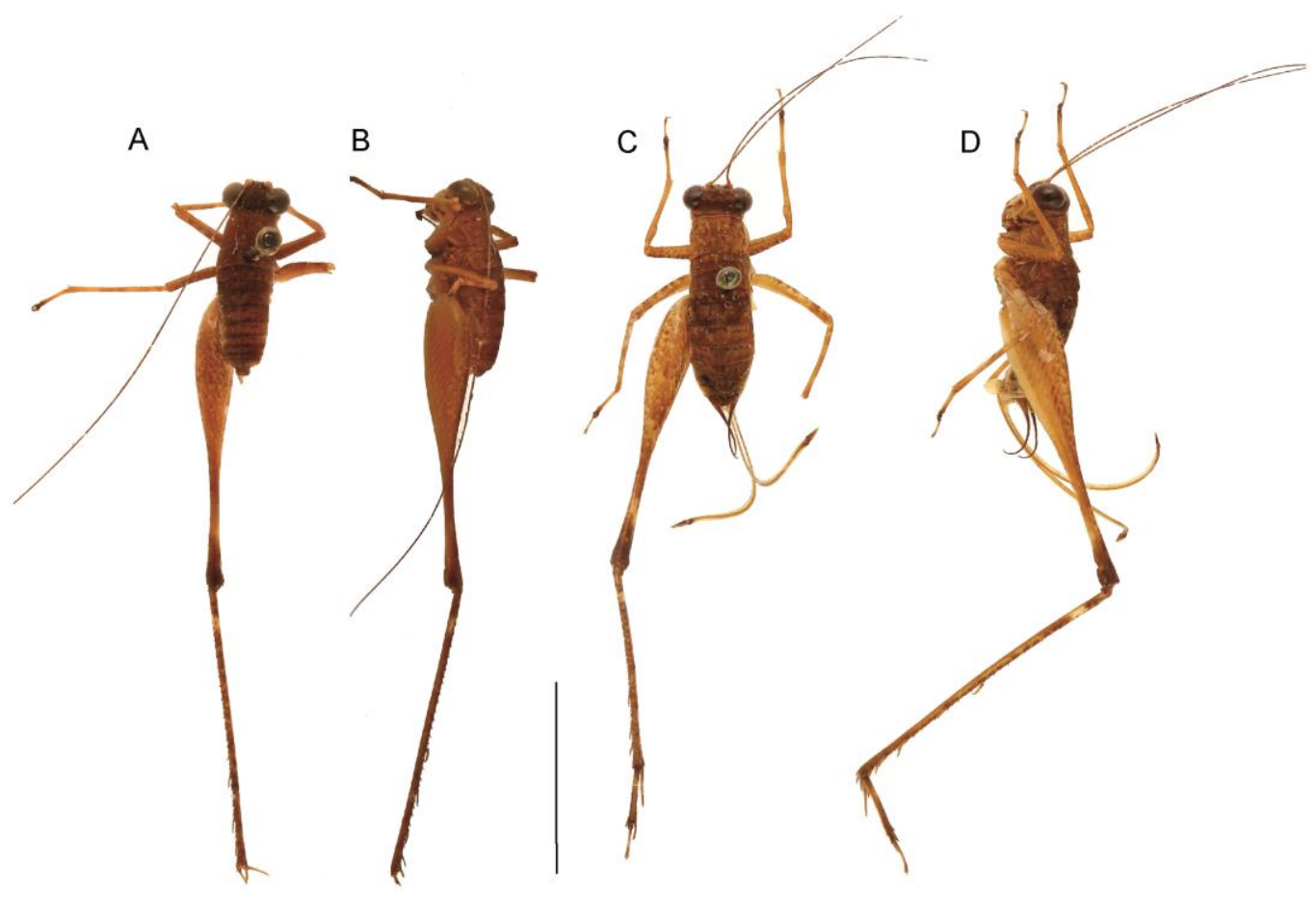


Fig.4.

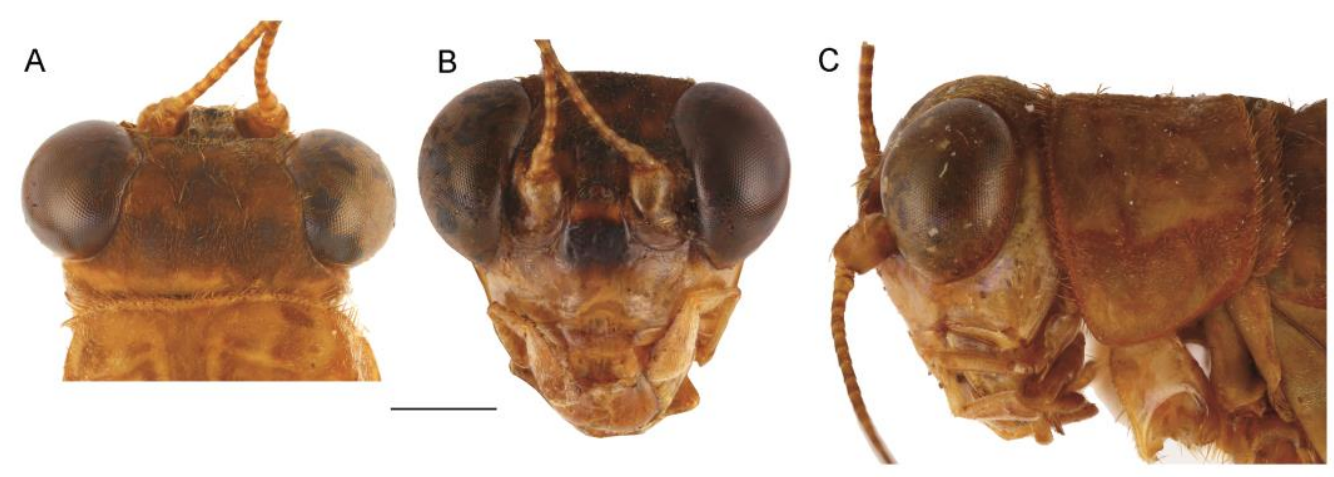


Fig.5
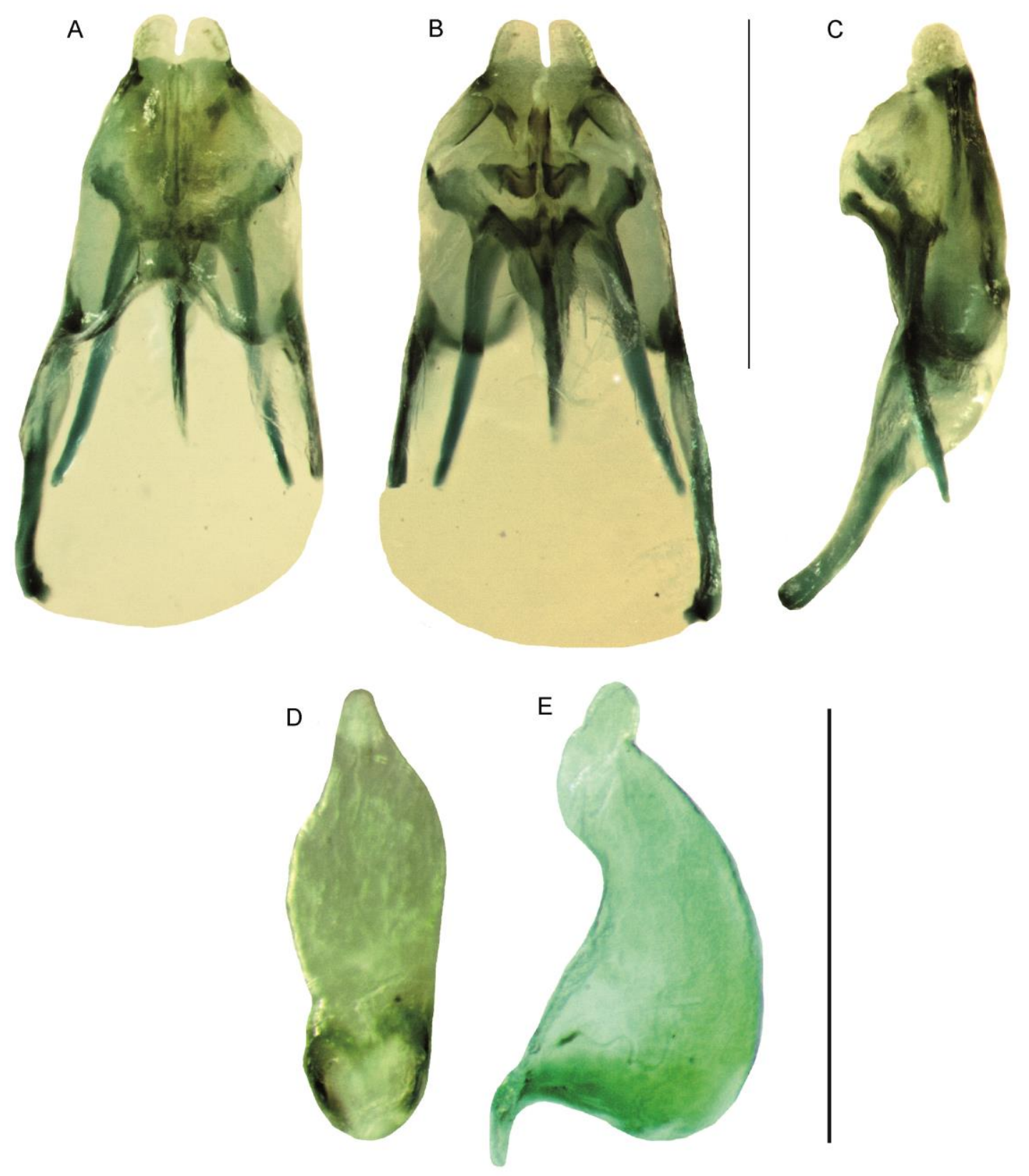
Fig. 6.
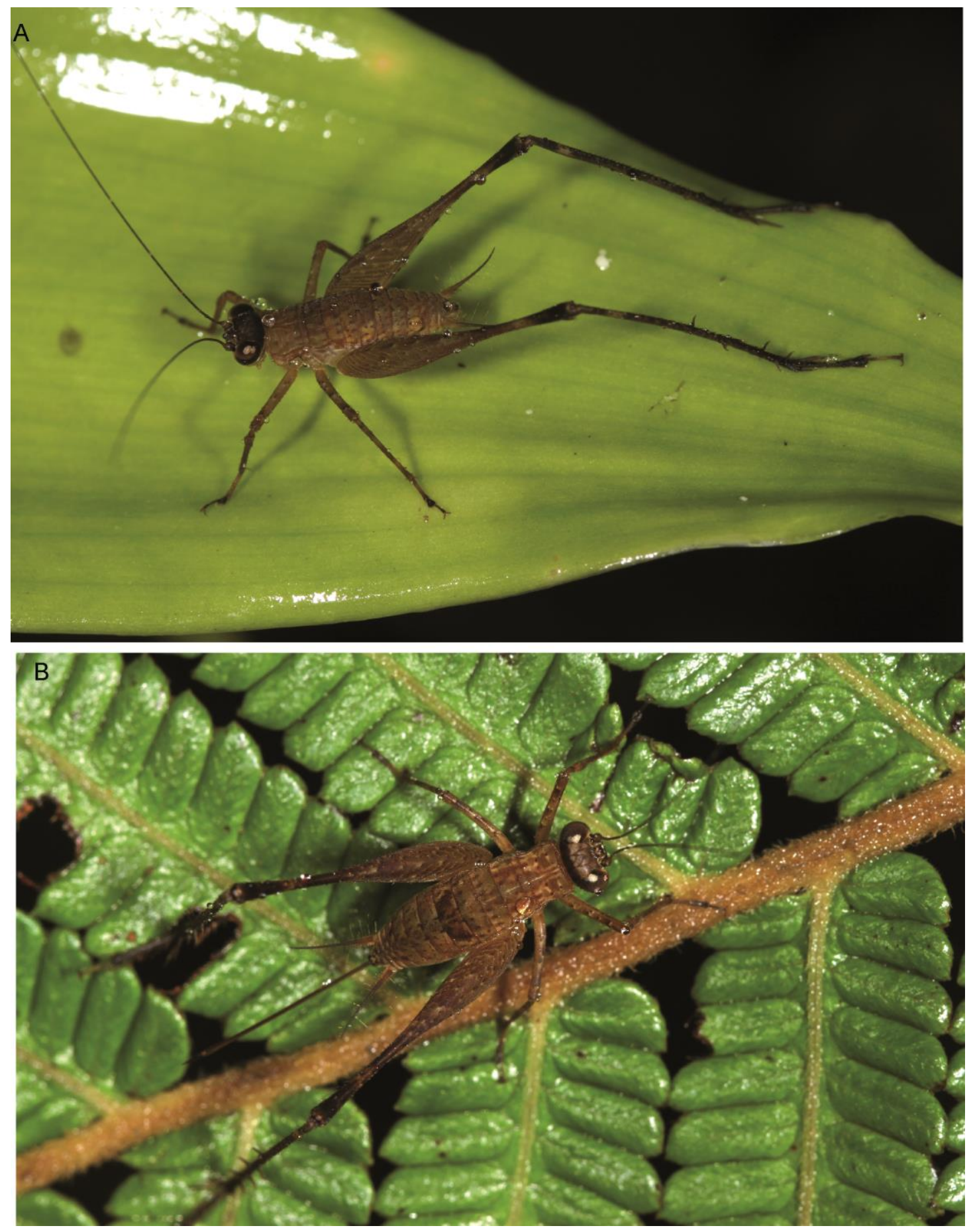
Fig.7.

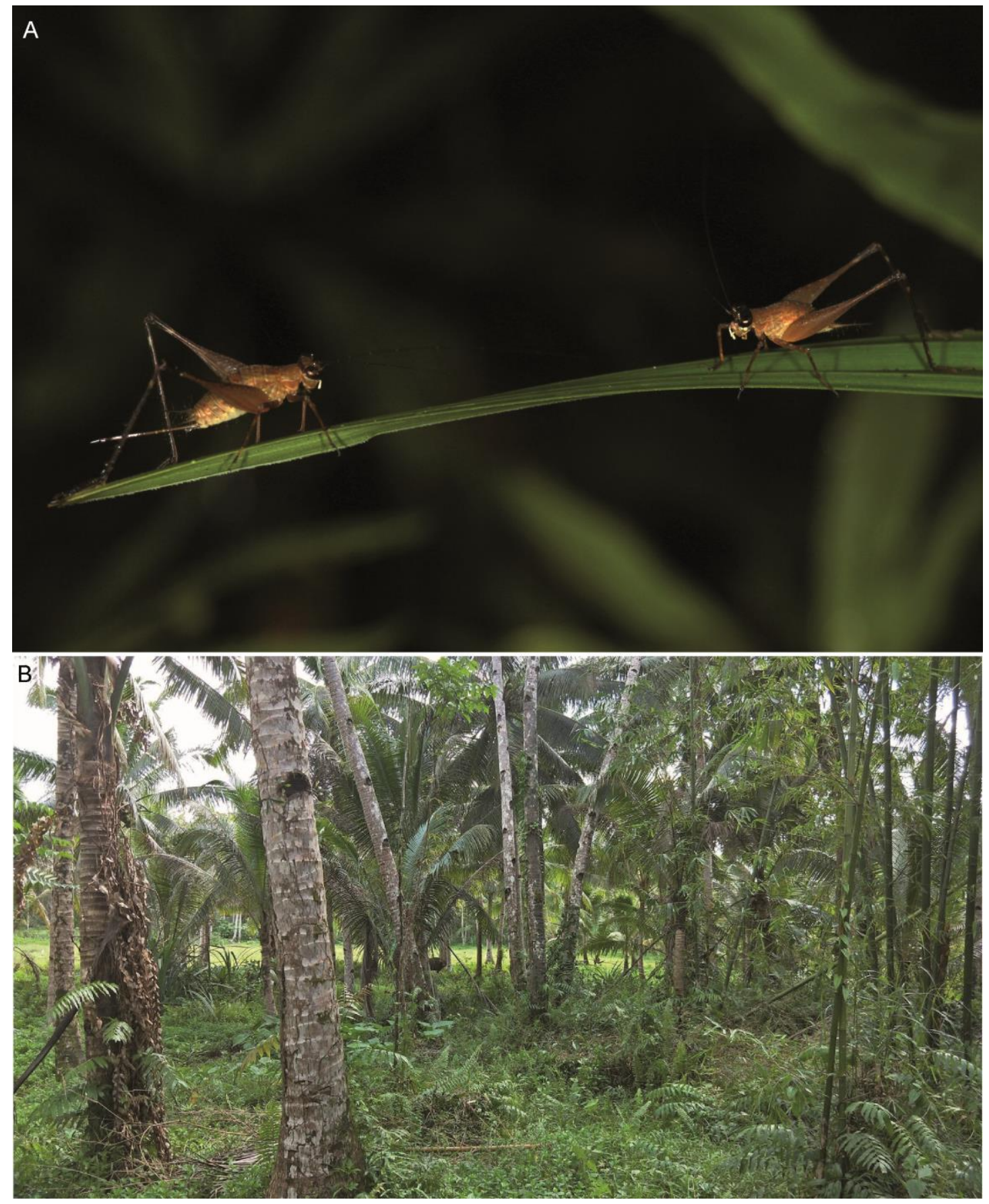


Fig. 8.

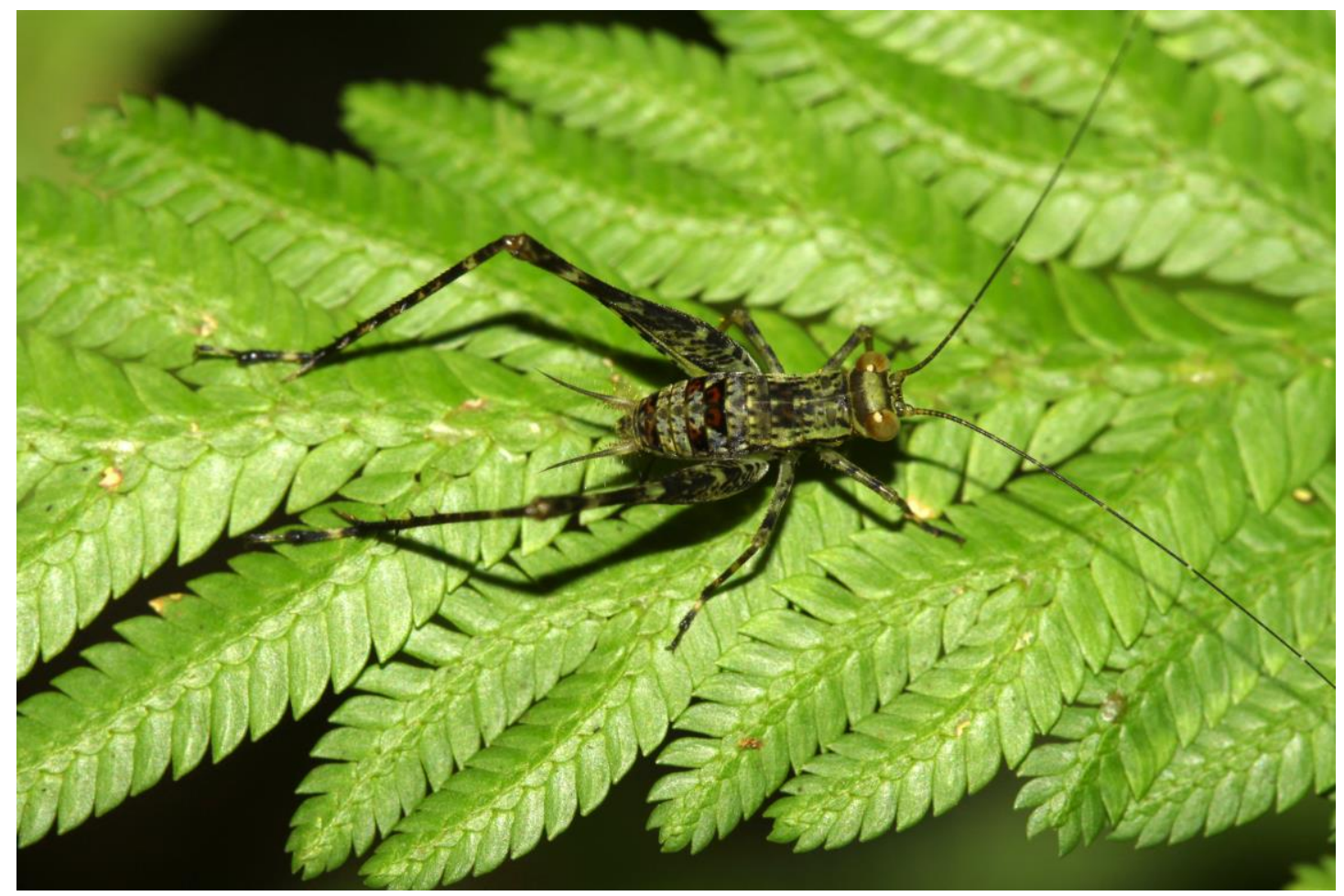

